\title{
USAHA PUPUK ORGANOPLUS PADA PROGRAM KEGIATAN IPTEKS BAGI KREATIVITAS KAMPUS
}

\author{
N.M. Witariadi ${ }^{1}$ dan I.K Sardiana ${ }^{2}$
}

\begin{abstract}
ABSTRAK
Program kegiatan Ipteks bagi kreativitas kampus bertujuan untuk memacu jiwa kewirausahaan dikalangan insan kampus dan menyediakan pupuk organoplus bagi petani. Pupuk organoplus merupakan pupuk organik yang diperkaya mineral Mg (Magnesium) yang berfungsi untuk memperbaiki kualitas buah-buahan. Target kegiatan ini yaitu tersedianya sarana dan fasilitas produksi dengan kapasitas 50 ton. Metode pelaksanaan meliputi : bahan baku, proses produksi, manajemen, pemasaran, dan sumberdaya manusia. Kegiatan proses produksi diawali dari mensuplai bahan baku, produksi, packaging dan selanjutnya pemasaran pupuk. Pupuk organoplus memiliki keunggulan karena komposisi dan konsentrasi haranya jauh berbeda, dimana kandungan Mg dan kalium yang tinggi dapat memacu kandungan gula yang lebih tinggi pada buah-buahan. Pangsa pasar pupuk organoplus memiliki pangsa pasar yang spesifik (khusus), yaitu pelaku pertanian organik untuk tujuan agrowisata atau konsumsi wisatawan. Pemasaran dilakukan secara langsung, kemitraan dengan Pemda dan konsiniasi dengan kios pertanian. Dapat disimpulkan bahwa usaha kegiatan pupuk organoplus ini dapat membantu masyarakat memperoleh pupuk organoplus untuk memperbaiki kualitas buah dengan harga lebih murah.
\end{abstract}

Kata kunci: Organoplus, magnesium, kalium , dan pemanis buah

\begin{abstract}
The Science and Technology activity program for campus creativity aims to stimulate entrepreneurial spirit among campus people and provide organoplus fertilizer for farmers. Organoplus fertilizer is an organic fertilizer enriched with mineral Mg (Magnesium) which serves to improve the quality of fruits. The target of this activity is the availability of production facilities and facilities with a capacity of 50 tons. Implementation methods include: raw materials, production processes, management, marketing, and human resources. The production process activities start from supplying raw materials, production, packaging and then marketing fertilizer. Organoplus fertilizer has advantages because its composition and concentration are much different, where high content of $\mathrm{Mg}$ and potassium can stimulate a higher sugar content in fruits. The organoplus fertilizer market share has a specific (specific) market share, namely organic farming actors for agro-tourism or tourist consumption. Marketing is carried out directly, partnerships with local governments and consultation with agricultural kiosks. It can be concluded that this organoplus fertilizer business can help people obtain organoplus fertilizer to improve the quality of fruit at lower prices.
\end{abstract}

Keywords: Organoplus, magnesium, potassium, fruit sweeteners

${ }^{1}$ N.M. Witariadi Dosen Fakultas Peternakan universitas Udayana wityarimade@unud.ac,id

${ }^{2}$ I.K Sardiana Dosen Fakultas Peternakan Universitas Udayana ksardiana@unud.ac,id 


\section{PENDAHULUAN}

Pertanian organik di Bali mengalami perkembangan yang pesat, sejalan dengan kebijakan pemerintah Provinsi Bali melakukan langkah strategis dalam menuju pertanian organik, dan mewujudkan Pulau Bersih dan Hijau (Bali Clean and Green) dan pembangunan yang berkelanjutan. Dalam bidang pertanian menekankan upaya menuju pertanian organik dan ramah lingkungan,yang seiring dengan semakin berkembangnya "trend" gaya hidup sehat di masyarakat "back to nature", menyebabkan permintaan akan produk pertanian organik semakin meningkat. Latar belakang dikeluarkanya kebijakan ini karena mahalnya harga pupuk kimia sintesis, munculnya berbagai persoalan lingkungan akibat pencemaran residu pupuk kimia, dan permintaan akan produk organik untuk memenuhi kebutuhan wisatawan dan agrowisata. Meningkatnya kebutuhan masyarakat terhadap produk pertanian organik, mendorong petani untuk memproduksi produk organik. Kebijakan Pemerintah Provinsi Bali dengan memberikan subsidi pupuk organik sebanyak 19.650 ton pada tahun 2014 meningkat menjadi 23.000 ton pada tahun 2015, dan akan terus meningkat pada tahun mendatang. Kabupaten Tabanan sebagai sentra pertanian padi dan sayuran organik diperkirakan mampu menyerap pupuk organik mencapai 10.000 ton/tahun. Kondisi tersebut menunjukkan bahwa usaha pupuk organoplos memiliki peluang besar.

Persoalan yang dijumpai dilapangan adalah pupuk yang diproduksi masih belum memenuhi standar kualitas sesuai Standar Nasional Indonesia (SNI). Pupuk organik berdasarakan standar nasional Indonesia (SNI) yaitu mengandung hara untuk tanaman yang lebih lengkap dengan dosis yang lebih tinggi. Beberapa penelitian untuk menghasilkan pupuk organik yang berkualitas sudah dilakukan di Universitas Udayana. Perbaikan kualitas pupuk organik untuk memenuhi standar SNI dilakukan melalui diversifikasi komposisi material, pemanfaatan fermentor yang lebih efektif, dan perbaikan proses pengolahan. Material tersebut terdiri dari : limbah kotoran ayam, limbah ampas anggur, dan limbah arang sekam. Kemudian diperkaya dengan bahan mineral alam sumber magnesium $(\mathrm{Mg})$ yang dihasilkan dari penambangan batu limestone di Bukit Jimbaran Kabupaten Badung, Bali. Melalui teknik tersebut dihasilkan pupuk dengan komposisi hara NPK lebih tinggi serta mengandung unsur magnesium dan hara mikro yang signifikan.

Memperhatikan kondisi diatas mendorong untuk mengembangkan formulasi pupuk hasil penelitian tersebut untuk diproduksi dalam sekala ekonomi untuk tujuan komersial. Usaha ini merupakan upaya untuk komersialisasi produk intelektual kampus yang dapat menjadi sumber income generating bagi kampus. Selain itu, usaha produksi produk tersebut juga dapat menjadi wahana magang bagi mahasiswa untuk mengembangkan kompetensi kewirausahaan mahasiswa.

\section{METODE PELAKSANAAN}

Proses produksi pupuk organoplus dimulai dari penyiapan material berupa kotoran ayam, limbah anggur, batuan magnesium, dan fermentor. Pada tahapan produksi pupuk organoplus ini dilakukan langkah-langkah sebagai berikut:

\begin{tabular}{|c|c|c|c|c|c|c|c|c|}
\hline $\begin{array}{l}\text { Material } \quad+ \\
\text { fermentor } \\
\text { (ditutup } \\
\text { terpal) }\end{array}$ & 4 & $\begin{array}{l}\text { Diayak pada } \\
\text { mesin } \\
\text { pengayak }\end{array}$ & $\lambda$ & $\begin{array}{l}\text { Diolah } \\
\text { pada mesin } \\
\text { granulasi }\end{array}$ & 4 & $\begin{array}{l}\text { Dikeringkan } \\
\text { pada rotary } \\
\text { drayer }\end{array}$ & 4 & $\begin{array}{l}\text { Ditimbang } \\
\text { dan dikemas } \\
\text { (Siap } \\
\text { dipasarkan) }\end{array}$ \\
\hline
\end{tabular}

Gambar 1. Alur Proses Produksi Pupuk Organoplus 
Bahan baku untuk memproduksi pupuk organoplus antara lain: kotoran ayam petelur (sumber Nitrogen), limbah anggur dan sebuk arang (sumber Phosphat, Kalium dan karbon), mineral magnesium karbonat (kadar $\mathrm{Mg}>20 \%$ ).

\section{HASIL DAN PEMBAHASAN}

Jenis bahan baku yang dipakai membuat dalam memproduksi organik adalah ayam petelor sebagai sumber Nitrogen $(\mathrm{N})$, limbah anggur sebagai sumber Phosphat $(\mathrm{P})$ dan Kalium $(\mathrm{K})$. Bahan utama dicampur dan difermentasi sehingga dihasilkan pupuk organik yang sudah distandardisasi memakai Peraturan Menteri Pertanian. Kotoran ayam diperoleh dari kelompok peternak ayam binaan Fakultas Peternakan Universitas Udayana di Desa Babahan Penebel. Kandungan kotoran ayam adalah sebagai berikut: $2.79 \% \mathrm{~N}, 0.52 \% \mathrm{P}_{2} \mathrm{O}_{5}, 2.29 \% \mathrm{~K}_{2} \mathrm{O}$. Ampas anggur diperoleh dari perusahan anggur di Tabanan mempunyai kadar C-organik 45.3\%, N 2.98\%, P 0.18\% dan K $2.26 \%$, selain itu akan memberikan unsur $\mathrm{Ca}, \mathrm{Mg}, \mathrm{Mn}, \mathrm{Fe}, \mathrm{Cu}$, dan $\mathrm{Zn}$ (Laboratorium Tanah, 2005).

Produksi pupuk organoplus dilakukan melalui tahapan yaitu : Persiapan material pupuk seperti Fermentor (probiotik) efektif berupa bioinokulan berbasis limbah cairan rumen yang memiliki daya urai efektif sehingga mampu menguraikan material bahan organik secara lebih cepat dan sempurna. Limbah kotoran ayam ras diperoleh dari kelompok peternak binaan Universitas Udayana di sentra peternakan ayam ras masyarakat di Desa Babahan Kecamatan Penebel Kabupaten tabanan. Ampas anggur yang diperoleh dari pabrik wine di Kecamatan Kerambitan Kabupaten Tabanan.

Pengolahan diawali dengan pencampuran material pupuk dengan komposisi 500 kotoran ayam, $200 \mathrm{~kg}$ arang sekam, $200 \mathrm{~kg}$ ampas anggur, $100 \mathrm{~kg}$ mineral alam sumber $\mathrm{Mg}$, dan 4 botol decomposer. Campuran ditimbun dan ditutup rapat dengan terpal dan bagian pinggir terpal diberi beban sehingga jika ada angin terpal tidak terbuka. Diamkan selama 3 hari, kemudian terpal dibuka dan timbunan diaduk untuk tujuan pemberian airasi pada proses pengomposan. Proses pengomposan yang berhasil akan timbul panas dan dapat dirasakan saat pembongkaran gundukan. Perkirakan setelah 2 minggu pupuk sudah bisa dibongkar dan diangin anginkan supaya menghilangkan bau amoniak dan sudah dapat dipakai. Pupuk yang sudah masak selanjutnya di ayak sesuai keinginan kemudian di kemas. Untuk granular, langkah berikutnya di proses dalam mesin granular untuk selanjutnya dikemas, siap dipasarkan.

Produk pupuk organik hasil kegiatan ini sebelum dipasarkan akan dilakukan pengurusan sertifikatnya, yaitu untuk memperoleh ijin edar, sertifikat dari Badan Pupuk Nasional, SNI, dan Departemen Pertanian. Pemakaian pupuk organik di lapangan akan diberikan buku panduan yang dapat dimengerti dengan mudah oleh kelompok pertanian atau Petugas Penyuluh Lapangan.

Kapasitas produksi usaha pupuk organoplus sebesar 50 ton, dengan harga jual Rp.3.000/kg. Kendala utama untuk mencapai target kapasitas produksi sangat ditentukan oleh ketersediaan bahan baku, tenaga kerja yang terlibat dalam proses produksi dan kelancaran permintaan atau pemasaran. Mengatasi kekurangan bahan baku khususnya ampas anggur dan sekam arang dengan melakukan kerjasama dengan perusahan anggur dan penyosohan gabah di kabupaten Tabanan. Limbah kotoran ayam sampai saat ini masih bisa diatasi dengan bekerjasama kepada peternak di desa Bahahan, Penebel. Kendala juga dialami di tenaga kerja, yang mana saat ini tenaga kerja yang memproduksi pupuk menggunakan tenaga lokal yang lebih sering libur kartena beberapa alasan diantaranya acara agama. Menghindari kekurangan produk pupuk, maka diusahakan saat tenaga kerja tidak banyak kegiatan di desa selalu bekerja, sehingga stok pupuk selalu tersedia. Kendala pemasaran yang utama adalah produk yang dihasilkan belum dikenal secara luas, maka langkah prioritas kedepan adalah dengan mengintensifkan aktivitas promosi, menjalin kemitraan dengan 
Produk pupuk organoplus sebagian besar terserap melalui program pemerintah pemberian pupuk organik bersubsidi bagi petani. Pemasaran lain adalah mensuplai kebutuhan pupuk agrowisata pertanian organik (stroberri dan sayuran organik di Kecamatan Baturiti, Kabupaten Tabanan), dan pemasaran langsung kepada konsumen dilakukan dengan membuka otlet di pasar pertanian Beringkit. Pasar potensial yang menyerap produk pupuk organoplus dalah petani hortikultura dan sayuran organik di Bali yang kebutuhannya mencapai 22.000 ton per tahun.

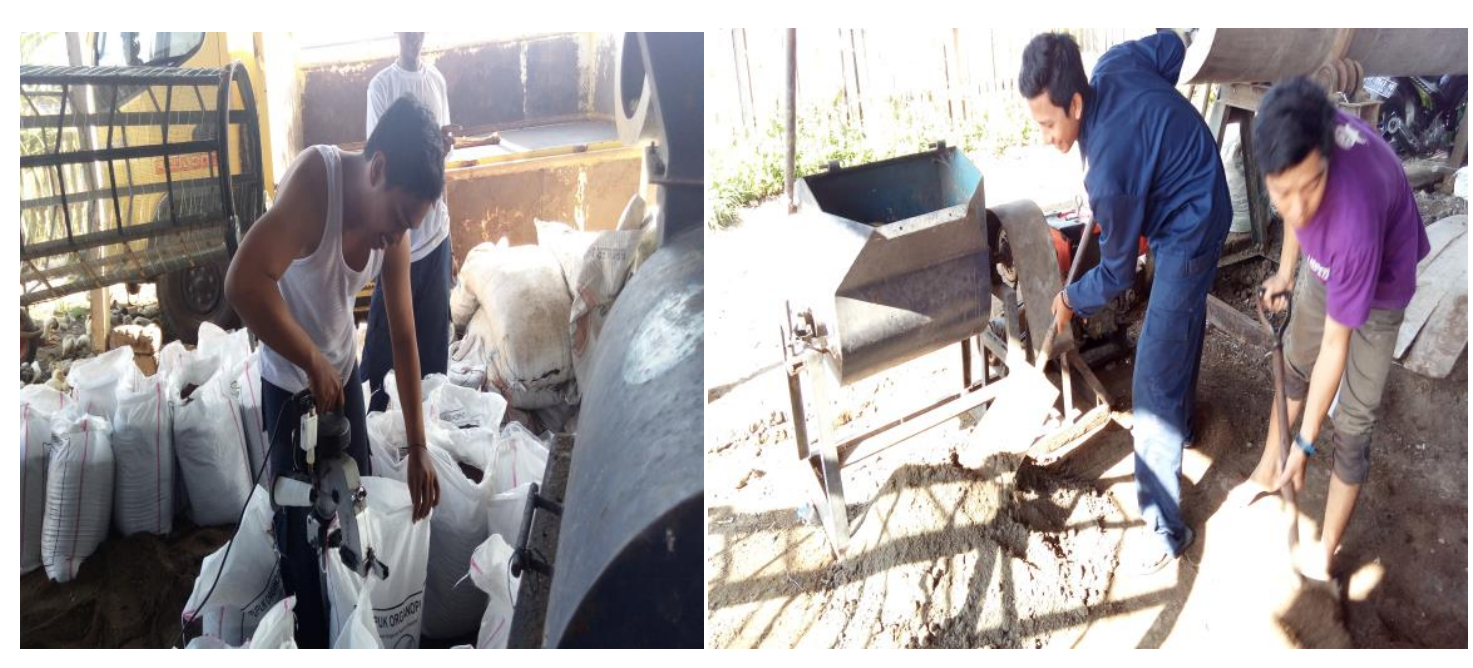

Gambar 1. Proses produksi pupuk organoplus

\section{SIMPULAN}

Berdasarkan hasil kegiatan usaha pupuk organoplus diatas, dapat disimpulkan bahwa : 1) usaha ini sangat membantu dalam menyediakan pupuk organik yang memenuhi standar SNI untuk memperbaiki kualitas tanah dan produk pertanian hortikulura lainya; 2) kapasitas produksi sebesar 50 ton dengan sasaran pemasaran kepada pelaku pertanian organik dan hortikultura.

\section{UCAPAN TERIMAKASIH}

Penulis mengucapkan terimakasih kepada Direktorat Riset dan Pengabdian Masyarakat Kementerian Riset, Teknologi dan Pendidikan Tinggi atas dana yang diberikan melalui skema PPUPIK, Rektor Universitas Udayana melalui ketua LPPM Universitas Udayana yang telah memberikan fasilitas sehingga kegiatan pengabdian ini terlaksana sesuai dengan rencana.

\section{DAFTAR PUSTAKA}

Downey,W.D. dan Ericson,S.P. 1992. Manajemen Agribisnis. Edisi Kedua, Cetakan Ketiga. Erlangga, Jakarta.

Kotler, P. 1997. Manajemen Pemasaran. Jilid 1 dan 2. Penerbit Prenhallindo, Jakarta

Manullang, M. 2005. Dasar Dasar Manajemen. Gadjah Mada University Press, Yogyakarta.

Mosher, A. T. 1987. Menggerakkan dan Membangun Pertanian. CV Yasaguna, Jakarta

Mubyarto, 1989. Pengantar Ekonomi Pertanian. LP3ES, Jakarta.

Sardiana, I.K., B.R.T. Putri, I.G. Suranjaya, N.L.R. Purnawan. 2015. Pengembangan Kewirausahaan Di Universitas Udayana. Majalah Aplikasi Ipteks Ngayah : Vol. 6, No. 1, hal. 91-101 
Sardiana, I.K., I.M. Adnyana, I.B.P. Manuaba and I.G.A.M S Agung. 2014. Soil Organic Carbon, Labile Carbon and Organic Carbon Storage under Organic and Conventional Systems of Chinese Cabbage in Baturiti, Bali Indonesia. Journal of Biology, Agriculture and Healthcare. Vol. 4. No. 21. Pp. 63-71

Suparta, I.N., Budiartha,I.W., Suciani, Putri,B.R.T., Agribisnis Peternakan Meraih Kesempatan Menuju Sukses. Pustaka Nayottama, Denpasar.

Suryana. 2008. Kewirausahaan. Pedoman Praktis: Kiat dan Proses Menuju Sukses. Edisi Ketiga. Salemba Empat, Jakarta. 